too, of another fault running along the eastern margin of the bay through Santa Rosa and north-westwards along the valley of the Russian river past Ukiah, which may have been concerned in the violence of the earthquake at those places.

Two other articles in the same magazine deal with the times at which the disturbance was recorded by seismographs. From them we gather that the shock was recorded on a self-registering seismograph in the University of California at $5^{\mathrm{h}}$. $12 \mathrm{~m}$. $3^{8 \mathrm{~s}}$. a.m. Pacific time, equivalent to $\mathrm{rh}$. $12 \mathrm{~m}$. $38 \mathrm{~s}$. p.m. Greenwich time. The seismograph of the United States Weather Bureau at Washington, 2435 miles distant from San Francisco, recorded the commencement at $8 \mathrm{~h}$. I9m. 20 s. eastern time, corresponding to Ih. Igm. 2os. Greenwich time, and the seismographs of the United States Coast and Geodetic Survey at Sitka, Alaska, and Chelten-

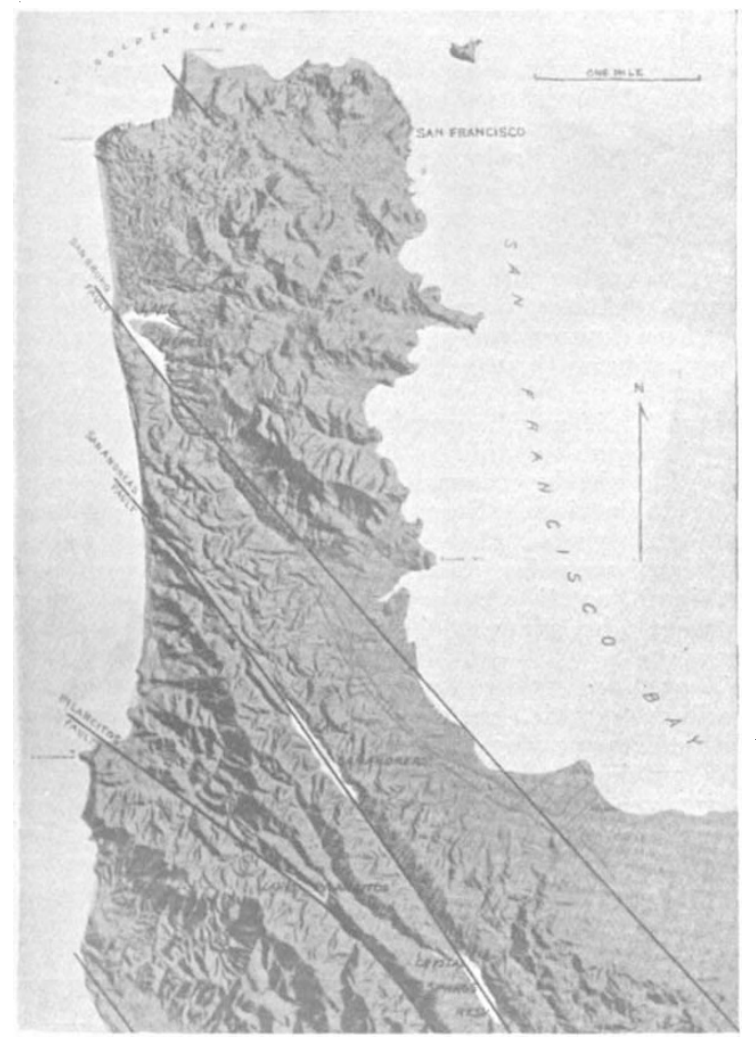

Fig. 2.-Map of the San Francisco Peninsula. From the model by
Prof. A. C. Lawson. The principal faults are indicated by heavy black lines. From the National Geographic Magazine.

ham, Maryland, also recorded the shock, commencing at $\mathrm{ih}$. $16 \mathrm{~m} .56 \mathrm{~s}$. and $\mathrm{Th}$. $\mathrm{I} 9 \mathrm{~m}$. 24s. respectively, the distances from San Francisco being I455 and $245^{\circ}$ miles. The magnetographs at these two places and at Baldwin, Kansas, were also affected by the passage of the earthquake waves, the times corresponding approximately with those of the arrival of the principal, or third, phase of the disturbance.

\section{THE FORTHCOMING MEETING OF THE BRITISH ASSOCIATION AT YORK.}

THE arrangements for this meeting, which will 1 be held from August i to August 8, are very well in hand, being at least a month in advance of what they were twenty-five years ago, on the occasion of the jubilee meeting-one of the most No. I 9 I 2, voL. 74 ] successful ever held. The local fund now reaches more than $3000 l$, and the greater part having been already paid up, the fund has been closed. The various committees are meeting regularly, secure good attendance, and the greatest interest and enthusiasm prevails. One of the local secretaries, Mr. Dale, having died, Mr. Henry Craven, who has succeeded him in the office of town clerk, has been appointed his successor.

The following is an epitome of the general attractions included in the programme :-

Wednesday, August I.-The Lady Mayoress (Mrs. R. H. Vernon Wragge) will be "At Home" at the Mansion House from 3 p.m. to 6 p.m. to receive foreign visitors, members, associates, and lady ticket-holders. President's address in the exhibition buildings at 8.30 p.m.

Thursday, August 2.-The Sheriff of York and Mrs. Bentley will give a garden-party at their residence, Fulford Grange, to all ticket-holders, from 3 p.m. to 6 p.m. Conversazione in the exhibition buildings, by invitation of the executive committee, at 8 p.m. Music will be provided in the museum gardens, which communicate with the building and will be illuminated.

Friday, August 3.-Messrs. Rowntree and Co. will give a garden-party at their works, Haxby Road, to all ticketholders, from 3 p.m. to $6 \mathrm{p} . \mathrm{m}$. The works will also be open. Discourse on volcanoes, by Dr. Tempest Anderson, in the exhibition buildings at $8.30 \mathrm{p} . \mathrm{m}$.

Saturday, August 4.-The Archbishop of York and Mrs. MacLagan will give a garden-party at the Palace, Bishopthorpe. Evening lecture to the operative classes by Prof. Silvanus Thompson, F.R.S., on the manufacture of light. The president, Prof. Ray Lankester, will take the chair.

Sunday, August 5.-Special service in the Minster.

Monday, August 6.- The council of the Yorkshire Philosophical Society will give a garden-party in the museum grounds, to all ticket-holders, from $3 \mathrm{p} . \mathrm{m}$. to $6 \mathrm{p} . \mathrm{m}$. They have also intimated that the museum and grounds will be open daily to all members and ticket-holders who wish for a quiet resting-place. The president of the society, Dr. Tempest Anderson, will entertain to tea those who attend each afternoon. Discourse on the electrical signs of life, and their abolition by chloroform, by Dr. A. D. Waller, F.R.S., in the exhibition buildings, at $8.30 \mathrm{p.m}$.

Tuesday, August 7.-The Dean of York and the Canon in Residence will give a garden-party, to all members and ticket-holders, in the Deanery and residentiary grounds, from $3 \mathrm{p} . \mathrm{m}$. to $6 \mathrm{p} . \mathrm{m}$. Conversazione in the exhibition buildings, by invitation of the executive committee, at 8 p.m. Music will be provided in the museum gardens, which will be illuminated.

Wednesday, August 8.-Meeting of general committee to receive the report of the committee of recommendations, I p.m. Concluding general meeting, in the Guildhall, at 2.30 p.m.

It is understood that a large number of important papers has been already promised, and it will be noticed that an unusually attractive series of gardenparties and receptions has been provided. In fact, the number offered has been so large that several very eligible offers of hospitality have had to be reluctantly declined. Practically all the principal residents in York and the neighbourhood have invited members of the association for the time of the meeting, besides a large number of private friends; who will swell the lists of members and associates attending.

The proposed excursion to Norway at the close of the meeting has fallen through, as little interest or support seemed forthcoming. The excursions will therefore be confined to Saturday, August 4, and the following have been definitely fixed:-

Scarborough and Whitby, stopping at Castle Howard.The Mayor of Scarborough has intimated that he will be "At Home" to a limited number of those taking part in the excursion. Permission has been granted to view the Marine Drive, and the members and associates will be 
idmitted to the Spa on the production of their tickets. It has also been arranged that the train shall stop at Castle Iloward to enable any members to pay a visit, but it is understood that only a portion of the house and gardens will be available.

Harrogate, Brimham Rocks, and Pateley Bridge: conductor, Mr. W. Ingham.

Ripon, Studley Park, and Fountains Abbev.-The Marquess of Ripon has kindly promised to entertain a party of about 100 to luncheon, and the Mayor of Ripon will entertain the same party to tea.

Ilkley and Bolton Abbey.

Coxwold, Byland Abbey, Helmsley, Duncombe Park, and Rievaulx Abbev. - It is expected that the party will be entertained at Duncombe l'ark by the Farl of Feversham; conductor, the Rev. C. N. Gray.

Wensleydale; conductor, Mr. W. Horne.

Mount Cirace, Cruisborough, and IVhorlton Castle.-Admiral Challoner has kindly invited the party to dinner, and it is expected that the Iord-Lieutenant of the North Riding will provide luncheon; conductor, Mr. F. J. Munby.

Driffield, Kirkburn, Wetwans, \&c.; conductor, the Rev. E. Maule Cole.

Aldborough and Boroughbridge.-Three steam launches have been engaged to convey the party; conductor, Mr. A. S. Lawson, who will provide luncheon and tea.

A small guide-book will be prepared for each of the above excursions. It is understood that there will be also the usual semi-private excursions arranged in connection with several of the sections.

The exhibition of South African photographs taken by the members last year promises to be of much interest. There is ample accommodation for it at the reception room, and an active committee has the matter in hand.

\section{KEW PUBIICATIONS.}

THE "miscellaneous information" supplicd from the Royal Gardens at Kew has ever been welcome to botanists and to those concerned in the utilisation of vegetable products. The earlier publications of Sir William Hooker and of his son and successor, Sir Joseph Hooker, are full of interesting matter with which the botanical and horticultural Press of the day was, owing to limitations of space, hardly able to cope.

Of late years such was the pressure of administrative duties that the publication of the Bulletin became very erratic. So much was this the case that we had almost given up the hope of seeing anything but "appendices" to volumes that seemed never destined to appear. In this we were mistaken. Within the last month or two we have received for notice the Kew Bulletin for the years 1900 , 1901 , 1902, I903, I904, and 1905.1

Some of these volumes are of exiguous proportions, but there they are, and the troubles of librarians and bibliographers are, in so far, set at rest. Much of the information is, of course, far from being up to date, and in some cases the gentlemen mentioned as having been appointed to fill certain positions have paid the debt of Nature before their nomination has thus been made public.

In spite of these circumstances we can but rejoice that the publication has been resumed, and that the sequence of the volumes is no longer interrupted. The contents are so "miscellaneous" that they do not lend themselves to anything like systematic review. We can only put the books on our reference shelves and welcome the fact, not only that the old gaps are, to some extent, filled up, but that there is now crery prospect of the regular issue of that Bulletin to

1 "Bulletin of Miscellaneous Information." Royal Botanic Gardens, Kew. (H.M. Stationery Office, 19(x)-05.)

No. I 912 , VOL. 74] which we look for an official record of the manifold and most important work done at kew.

A "Catalogue of Portraits of Botanists Exhibited in the Museums of the Roval Botanic Gardens, Kew," by Mr. James I). Milner, clerk and acting assistantkeeper and secretary to the National Portrait Gallery, has also just been published. The catalogue is introduced with a preface by the late director of the Royal Gardens. To botanists it forms a very interesting, but, we must add, a very inccmplete list. Kew probably possesses a nuch larger number of portraits. than are here mentioned, so that it is difficult to understand on what principle the selection has been made. 'The words " exhibited in the museums" do indeed imply that there are other portraits not thus displayed, but unless we are mistaken, or unless some re-arrangement has taken place recently, there are not a few hanging on the walls of the museums which are not included in the list. At any rate, we look in vain for any mention of the Balfours, father and son, of John Ball, of Broome, Babington, B. C. Clarke, Casimir de Candolle, W. T. Thiselton-Dyer, Eichler, Engler, A. Dickson, Farmer, Gardiner, Munro, Miers, Prain, Reichenbach, Seemann, Williamson, and many others whom it would be tedious to enumerate. No doubt many of these are "kept in portfolios," and can be inspected on application, but the absence in the catalogue before. us of even the names of these more or less distinguished botanists grives an impression of serious incompleteness which is probably not justified by the facts. This is the more unfortunate as the collection is stated to be "probably unique." If so, the catalogue is very inadequate, as maty be seen, not only by the few illustrations we have cited, but also by comparison with Dr. Wittrock's much fuller "Catalogus Stockholmiensis." The text. too, requires revision. In one place we are told of a bust wearing spectacles, and of another bust " in a ruff and fur-lined coat." On another page we are told of a botanist who graduated eighteen years before he was born!

There are other indications of imperfect proofreading, to which we direct attention in the hope that the defects may be remedied in a subsequent edition. The catalogue, even in its present condition, is of such rreat interest that we cannot doubt that no long time will elapse before a second edition is called for, and one which can readily be made more representative of the progress of botany, especially in our own country.

\section{BARON C.R. VON DER OSTEN SACKEN.}

SYSTEMATIC entomology has sustained a great loss by the death of Baron Osten Sacken, as announced in NATLRE of MaY 31.

Baron Osten Sacken was born at St. Petersburg on Augrust 21,1828 , and at the age of eleven his interest in entomology was aroused by his meeting, at Baden-Baden, a young Russian entomologist, Mr. Shatiloff, who gave him his first instructions in collecting Coleoptera. Between 1849 and 1856 he held an appointment in the Imperial Foreign Office, and published papers on the re-classification of the Tipulidæ, as well as a list of the insects of the St. Petersburg district excluding Lepidoptera. His appointment, in 1856 , as secretary of the Russian Legation at VVashington opened up the second period of his entomological career in the Linited States. In I862 he was appointed Russian Consul-General at New York, a post which he resigned in $187 \mathrm{I}$, remaining, however, in America until 1877 .

During this period of twenty-one years the main 